\title{
Bacterial endocarditis over prosthetic valves treated with trimethoprim-sulphamethoxazole combination
}

\author{
Syed H. Shafqat, Syed Akhtar A. Shah, and Shauket A. Syed \\ From the Department of Cardiology and the Neuropsychiatric Unit, \\ finnah Postgraduate Medical Centre, Karachi, Pakistan
}

Successful treatment of staphylococcal endocarditis with trimethoprim-sulphamethoxazole combination (Septran) in a patient with aortic and mitral Starr valve prostheses is reported. The treatment lasted 7 weeks. There were no side effects.

During the past few years a number of reports have indicated the therapeutic effectiveness of the new synthetic chemotherapeutic agent trimethoprim (2,4-diamino-5-(3,4,5-trimethoxybenzyl) pyrimidine) used in combination with sulphamethoxazole in a wide range of bacterial infections (Noall, Sewards, and Waterworth, 1962; Schneider et al., 1965; Akinkugbe et al., 1968; Hughes, 1969). Staphylococcus aureus shows a consistently high sensitivity to trimethoprim in vitro.

This combination has also been effective in a case of endocarditis due to Esch. coli (Fowle and Zorab, 1970). This report describes the second case of bacterial endocarditis successfully treated with this combination. However, it is the first published report of the successful use of this chemotherapeutic agent in endocarditis involving prosthetic cardiac valves.

\section{Case report}

This patient, aged 44, had successful replacement of aortic and mitral valves with Starr-Edwards prostheses by $\mathrm{Mr}$. Cleland in June 1968 at Hammersmith Hospital, London. After the operation he led a normal life while on a maintenance dose of phenindione and digoxin for atrial fibrillation.

Ten months after operation he was admitted with 5 days' history of fever, with rigors ranging between $38^{\circ} \mathrm{C}$ and $39^{\circ} \mathrm{C}$. He was acutely ill and looked toxic. Splinter haemorrhages, petechiae, and clubbing of the fingers were absent. There were no signs of congestive heart failure. The liver and spleen were not palpable. The heart rate was 80 a minute at a temperature of $39^{\circ} \mathrm{C}$, and was irregular due to atrial fibrillation. There was no change in the size or auscultatory findings of the heart. Other systems showed no abnormality.

Repeated blood smears for malarial parasites were negative. $\mathrm{Hb}$ was $10 \mathrm{~g} / \mathrm{100} \mathrm{ml}$, white cell count $8,950 / \mathrm{mm}^{3} ; 69$ per cent neutrophils, 27 per cent lymphocytes, I per cent monocytes, and 3 per cent eosinophils; ESR $30 \mathrm{~mm}$ first hour (Westergren). The urine showed an occasional leucocyte but no red blood cells.

Chest $x$-ray showed no abnormality in the lung fields. The heart was moderately enlarged as before.

In the absence of positive clinical evidence and in the presence of atrial fibrillation bacterial endocarditis was thought to be less likely, yet repeated blood cultures were taken during the next 72 hours.

The enteric group of févers was considered a possibility in view of the fact that this is quite a common cause of pyrexia in this part of the world and also because of an obvious relative bradycardia. The patient was put on chloramphenicol $500 \mathrm{mg} 6$ hourly. There was no change in the temperature and by the 6th day of admission a few petechiae were observed on his conjunctivae and over the buccal mucosa. The urine which had been free of red cells till this time showed the presence of RBCs in one of the specimens. Quick's one-stage test was 39 seconds with a control of 18 seconds. Three blood cultures were reported to have grown a coagulase-positive Staph. aureus sensitive to chloramphenicol, penicillin, and erythromycin, but resistant to cloxacillin. A diagnosis of staphylococcal endocarditis was made and the treatment was changed to penicillin 20 mega units intravenously daily and erythromycin $200 \mathrm{mg}$ parenterally 4 -hourly. This combination has been shown to exhibit synergism on strains of staphylococci resistant to both (Herrell, Balows, and Becker, I960).

By the evening of the same day he suddenly developed a feeling of numbness and heaviness of the right half of the body. The neurological examination revealed left hemiparesis with cortical type of sensory loss on the same side. Speech, however, remained unaffected.

During the next few days the pyrexia showed 
no response to treatment in spite of considerable increase in dosage of intravenous penicillin, and he complained of pain in the left hypochondrium and various muscles of the body. By the I2th day of admission the patient had become more toxic and went into heart failure. The white cell count was $15,000 / \mathrm{mm}^{3}$ with 86 per cent polymorphs. An $x$-ray of the chest showed pulmonary oedema.

In view of the complete lack of response to penicillin and erythromycin combination, the latter was dropped and streptomycin was added instead. Carbenicillin was also started to give wider cover against any undiscovered Gramnegative bacteria. The pyrexia continued in spite of the use of all these antibiotics, and on the 17 th day he was put on trimethoprim $160 \mathrm{mg}$ and sulphamethoxazole (Septran) $800 \mathrm{mg}$ every 6 hours, while the benzyl penicillin intravenous drip was continued. In vitro studies did not demonstrate antagonism between penicillin and this combination. Neither was there any synergism.

After 24 hours of the administration of this combination a dramatic change was noticed in the condition of the patient. He felt better and lost his toxic look. The temperature began to show a downward trend after 36 hours and became completely normal after 5 days of start of therapy with the trimethoprim and sulphamethoxazole combination. Carbenicillin was stopped while benzyl penicillin was continued for 2 weeks. The combination was administered in the above dosage for 5 weeks; the frequency of administration was reduced to every 8 hours for another week and 12hourly for a further week. The total duration of therapy was 7 weeks.

Repeated blood counts done during the period of therapy did not indicate any adverse effect on the haemopoietic system. The ESR, which at the height of the illness was $80 \mathrm{~mm}$ in the first hour (Westergren), had fallen to $35 \mathrm{~mm}$ on discharge I I weeks after admission. It fell further to $27 \mathrm{~mm}$ 3 weeks later. When seen as an outpatient on 7 November 1969 four months after discharge he had returned to his job as principal of an engineering institution.

\section{Discussion}

In this case, the unresponsive pyrexia, an earthy and toxic look, petechial haemorrhages, microscopical haematuria, cerebral embolism, muscular pain, and positive blood cultures in the presence of prosthetic valves, established without any doubt the diagnosis of bacterial endocarditis.

Treatment of infections on prosthetic devices is a difficult and formidable problem. Chemotherapy usually fails to eradicate infection on the surface of a Starr valve. At

- times, therefore, it may be necessary to remove the valve (Beeson, 1967). Even with an organism which in vitro is sensitive to antibiotics, surgical removal may become mandatory if infection becomes entrenched in a mechanical prosthesis (R. Emanuel and D. N. Ross, 1968, personal communication to British Medical fournal, 1968).

W. P. Cleland found that isolation of bacteria might be difficult from the blood of the patient with prosthetic valves who develops bacterial endocarditis (I970, personal communication). He thinks that previous antibiotic therapy tends to promote the growth of low grade organisms which are difficult to grow in vitro. We were, however, lucky in that we were successful in growing Staph. aureus coagulase positive in 3 out of 9 blood culture specimens drawn. The lack of response to antibiotics shown to be effective in vitro did make us consider the possibility of additional undetected organisms.

After the failure of conventional antibiotics and impracticability of emergency prosthetic valve replacement operation, we decided to use trimethoprim and sulphamethoxazole combination (Septran). Previous reports of trimethoprim had indicated that its absorption is rapid after oral administration, effective plasma and high tissue levels being attained quickly and maintained for several hours.

This case gives an indication that this oral chemotherapeutic agent may prove effective against infection settling on foreign materials in the body and may obviate surgical intervention in a number of cases, especially for infections on prosthetic valves which carry an overall mortality of 75 per cent (Braimbridge, I969). The oral route of administeration is a considerable advantage.

We are grateful to Mr. W. P. Cleland and Professor J. F. Goodwin for their advice and comments on this paper.

\section{References}

Akinkugbe, O. O., Lewis, E. A., Montefiore, D., and Okubadejo, O. A. (I968). Trimethoprim and sulphamethoxazole in typhoid. British Medical fournal, 3, 721.

Beeson, P. B. (1967). Bacterial endocarditis. In CecilLoeb Textbook of Medicine, I2th ed., p. 703. Ed. by P. B. Beeson and W. McDermott. Saunders, Philadelphia.

Braimbridge, M. V. (1969). Cardiac surgery and bacterial endocarditis. Lancet, I, 1307.

British Medical fournal (1968). Emergency valve replacement in infective endocarditis. 1,5 .

Fowle, A. S. E., and Zorab, P.A. (1970). Esch. coli endocarditis successfully treated with oral trimethoprim and sulphamethxoazole. British Heart fournal, 32, 127.

Herrell, W. E., Balows, A., and Becker, J. (1960). Erythrocillin: a new approach to the problem of antibiotic-resistant staphylococci. Antibiotic Medicine and Clinical Therapy, 7, 637.

Hughes, D. T. D. (1969). Single-blind comparative trial of trimethoprim-sulphamethoxazole and 
ampicillin in the treatment of exacerbations of chronic bronchitis. British Medical fournal, 4, 470.

Noall, E. W. P., Sewards, H. F. G., and Waterworth, P. M. (1962). Successful treatment of a case of Proteus septicaemia. British Medical fournal, 2, IIOI.
Schneider, M., Schwarzenberg, L., Cattan, A., Schlumberger, J. R., Amiel, J. L., and Mathé, G. (1965). Essai de traitement de diverses infections à 'Proteus' par le 2,4-diamino-5-(3,4,5-trimethoxybenzyl) pyrimidine, (ou Triméthoprime). Presse Médicale, 73, 893. 